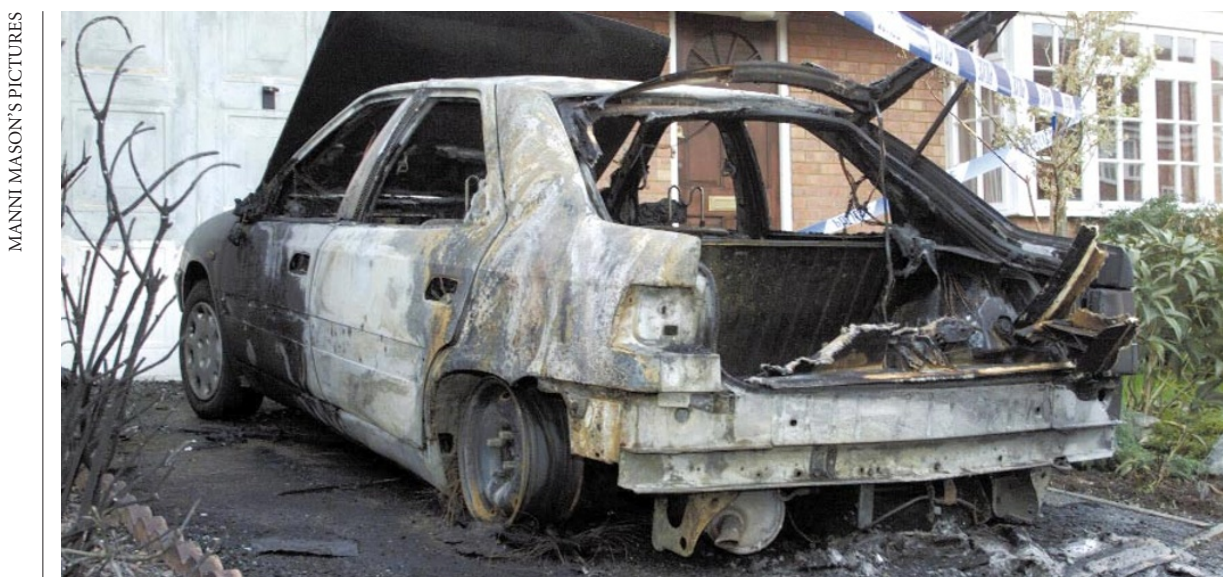

Burning issue: some activists resorted to illegal means in expressing opposition to animal research.

\title{
Animal-rights protests raise calls for UK government move
}

Georgina Kenyon, London

The British government is under intense pressure to do more to protect people associated with companies that perform experiments on animals, following last week's near-collapse of the Cambridgeshire-based company Huntingdon Life Sciences (HLS).

HLS came close to bankruptcy when one of its main backers, the Royal Bank of Scotland, withdrew its loan support. The bank had faced a campaign by animal-rights protesters that had targeted its directors.

The fate of HLS, one of the United Kingdom's largest animal-research contractors is being seen as a critical test of whether animal research can be protected from an array of protest actions. These have ranged from legal demonstrations, backed by legitimate animal-rights groups, to letter-bomb campaigns by anonymous extremists.

Jack Straw, the British Home Secretary, announced on 17 January that the government was considering tougher laws to stop two tactics being used by animal-rights activists: protests outside the homes of company directors and threats sent to them by mail.

But the Research Defence Society, a group representing scientists involved in animal experimentation, attacked the government's proposals as "too little and too late".

Barbara Davies, the society's deputy director, also questioned whether the government would actually implement changes in the law. "We need to see the government's words followed by action," she says. "We have been pressing for several months for legislation to outlaw [some] activists' violent campaigns against scientists and shareholders."

Groups opposed to animal research had recently extended their campaign from HLS itself to the bank. The bank had been considering whether to renew its loan facility of

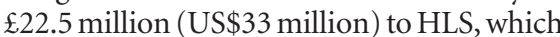

expired last Friday. But HLS reportedly secured new funding from unidentified backers in the United States. Groups such as Stop Huntingdon Animal Cruelty, whose policy is to support only peaceful and legal protests against animal research, say they will pursue their campaign against the new financiers if they are identified.

HLS was criticized for animal mistreatment in a 1997 British television programme, which showed HLS employees throwing a beagle against a wall and seriously harming other laboratory animals. The company has since replaced its management, and its supporters say its standards of animal care have improved.

A spokesperson for the Association of the British Pharmaceutical Industry says: "Nothing justifies the way these protesters have acted. We have to test on animals at this point in time. And if Huntingdon is forced to close, considerable damage will be done to the future of UK medical research.”

The association is currently in discussions with the government and other industry representatives over possible measures to prevent further demonstrations, and ease pressure on research laboratories to close.

The government has also been criticized by researchers for sending what they regard as ambiguous signals on its general policy towards the animal-rights movement. In particular, it failed to publicly support the concept of medical research on animals last year, when several pension funds that managed money for government employees withdrew money from HLS on ethical grounds.

Nancy Rothwell, a professor of physiology at the University of Manchester, says: "The government should introduce the possibility of withholding shareholders' and employers' names from the public. If HLS shuts down, the knock-on effect is a great concern for the research community."
Max Planck Society broke pledge to ask Jews back after war

Vera Bettenworth and Alison Abbott, Munich Germany's leading research organization reneged on a 1948 promise to contact Jewish scientists expelled from its laboratories during the Third Reich and offer them their jobs back, according to new research.

In fact, the research suggests, the Max Planck Society (MPS) tried only to tempt star scientists back to its fold. Most of these, including Albert Einstein, refused to return to Germany. Einstein thought his invitation was a whitewash attempt, and said he had "an irresistible aversion to being part of German public life again”.

Historian Michael Schüring has uncovered 85 cases of Jews or 'political undesirables' being expelled from the Kaiser Wilhelm Society, the MPS's predecessor. He adds that the true figure is probably higher, as documents may have been lost and witnesses are dying out. Only a small proportion of the cases he unearthed appear to have been contacted after the war, Schüring says.

Of these, only three agreed to return to work in Max Planck institutes, and one, geneticist Max Ufer, changed his mind when he learnt of the fascist past of some of the scientists he would have had to work with. Others were willing to have some level of scientific contact, for example as guest researchers or lecturers.

In the first three decades after the war, some dismissed members claimed compensation for damage to their careers on their own initiative. Thirty-three such cases are documented in the state and MPS archives. Of the 23 claims in the MPS archives, 14 were accepted in the form of one-off payments or pensions. All payments were made on a voluntary basis, the MPS refusing to accept legal obligation.

The research was commissioned by MPS president Hubert Markl, who has said the society "must definitely ask whether everything was done in the early years of the Max Planck Society to compensate for the shameful behaviour of the mid-1930s".

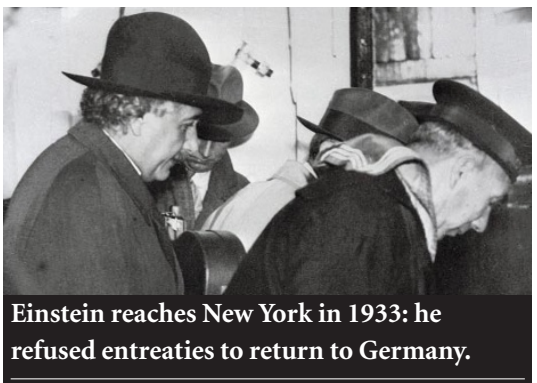

